\title{
Bioindicators of Plant and Animal Origin in an Ecosystem Evaluation
}

\author{
J. ŽÁK \\ Faculty of Education, Palacký University, Czech Republic
}

Received August 26, 2004

Accepted March 16, 2006

\begin{abstract}
Žák J.: Bioindicators of Plant and Animal Origin in an Ecosystem Evaluation. Acta Vet. Brno 2006, 75: 455-461.

The study had a threefold scientific objective: to perform a botanical survey of the area under study, to identify all plant species grazed by the European hare (Lepus europaeus) and to determine polychlorinated biphenyl (PCB) presence in hares using the screening test. The study area is characterized by intensive agricultural operations around the town of Senice in the Olomouc region. During the botanical survey in the agrocoenosis in 2001 and 2002, the author identified 62 species of herbs and grasses and 8 woody species. Of that total, 19 herbal and grass species and 6 woody species were suitable for consumption by the European hare. To determine the PCB concentrations, samples of plants, and the liver and muscle tissue from the front and hind extremities of the European hare were collected. PCB concentrations ranged from 0.0004 to 0.0007 $\mathrm{mg}$ in plants and 0.0001 to $0.0005 \mathrm{mg}$ in the liver and musculature of hares.
\end{abstract}

Congeners, screening, natural vegetation, PCB, Lepus europaeus

The excellent physiochemical characteristics of polychlorinated biphenyls (PCB) (thermo-stability, photo-stability, chemical inactivity, excellent heat-transferring characteristics etc.) have led to their extensive use practically in all the areas of human activity. In the last decades, however, PCB present high priority environmental contaminants and they are ranked among persistent organic pollutants (POPs).

The alarming moment was the finding of PCB in cattle in the village of Haňovice between 1985 and 1990, a merger of a number of small cooperative farms in the region into a gigantic agricultural co-operative JZD Senice, a conversion of a large part of the biotope into arable land that led to a more intensive use of artificial fertilizers ( $200 \mathrm{~kg} / \mathrm{ha}$ ) and pesticides $(8-12 \mathrm{~kg} / \mathrm{ha})$, and to an almost total disappearance of woody plant species from the agrocoenosis.

The possibility of using hares for environmental monitoring purposes has been studied by Bukovjan (1992). Relationships within the environment and suitable ecological conditions for animals were studied by Forman and Godron (1993). The issues of nutrition of the European hare in the meadow and the woody environments were dealt with by Homolka (1982,1987). Findings from other countries in the fields of rearing, ethology and nutrition of the European hare were reviewed by Kučera (1988). Polychlorinated biphenyls were demonstrated in soil, water, sediments, and plant and animal organisms by Piskač et al. (1990). Effects of PCB on hormonal activity, metabolism and fertility disorders were reported by Roots (1995), Jurajda and Bernardová (1996), Liang et al. (1999), Man os a et al. (2001). PCB has been demonstrated in fish, birds and mammals by Vávrová et al. (2003). Raszyk et al. $(1996,1997)$ reported faeces and manure as a possible source of PCB in agricultural ecosystems. These data emphasize the danger posed by BCPs and substantiate their inclusion among the $2 \mathrm{~A}$ category (carcinogenic substances).

\section{Materials and Methods}

The study took place over a flat 300 hectare area situated 236 - $247 \mathrm{~m}$ above sea level in the central part of the Upper Moravian Vale, 20 - $23 \mathrm{~km}$ westward of the city of Olomouc (Czech Republic). Individual tracks of

Address for correspondence:

MVDr. Jiří Žák

Faculty of Education, Biology Department

Palacký University

Purkrabská 2, 77200 Olomouc, Czech Republic

Phone: +420 58563518

E-mail: gabovaj@pdf.upol.cz

http://www.vfu.cz/acta-vet/actavet.htm 
agricultural land in that region are large (100 - 200 hectares), with few bushes and trees, baulks or dirt roads. The most frequently grown crops include wheat, barley and, to a smaller extent, sugar beet. Synanthropic vegetation is found along sporadic dirt roads, ditches and in strips of land along railway tracks.

During the botanical survey performed by the author in the area in 2001 and 2002, two samples of plants weighing $1 \mathrm{~kg}$ were collected in the fields, in ditches along hard-surface roads and along railway tracks. The plant species making up the hares' diet were identified based on the signs of gnawing, autopsy of the digestive tract, specifically stomachs, of hares bagged in that area during the autumn hunting season. The autopsies were made according to methods used by the Veterinary Anatomical Pathology Section of the Veterinary Investigation Institute in Olomouc. Stomach content was studied under a magnifying glass (at $10 \times$ magnification) and light microscope (CHK model, Made in Taiwan) (at $40 \times$ magnification). PCB levels were determined from plant specimens, and muscle tissue and liver of hare bagged on the territory under investigation. Samples collected were stored in a freezer until they were handed over for analysis.

The PCB screening tests were performed by the State Veterinary Institute in Olomouc on 22 samples of liver tissue, hare leg muscle tissue and grass. PCB content was defined as a sum of indicator congeners. The number of samples was limited because hares were scarce, and hare hunting was subsequently banned. Before the autopsy was made, the condition, health and sex of the hares studied were examined.

All 22 autopsied hares were well nourished and showed no symptoms of diseases or pathological changes in their organs. Both sexes were approximately equally represented. Their age structure was not very good because hares aged 1 and 2 years predominated.

For PCB determination, extracted fat samples weighing between 0.1 and $0.2 \mathrm{~g}$ were used. Fat samples were dissolved in $2 \mathrm{ml}$ of $\mathrm{n}$-hexane and quantitatively transferred to a chromatography column filled with active florisil. The eluting agent was a $70 \mathrm{ml}$ mixture of n-hexane and diethyl ether $(94: 6)$. The extract was evaporated by means of RVO and dissolved in $1 \mathrm{ml}$ of eluent. If some of coextracts were not removed by the column chromatography, additional purification was performed by acid hydrolysis using sulphuric acid. One millilitre of the purified extract was then closed and prepared for the HRGC/ECD analysis. The instruments used included:

a) HP5 column

b) instrument for the determination of GC-ECD, model 5890, Series II

c) standards - certification mixtures EPA (BAKER)

d) extracted fat (reference material) manufactured by EHRENSTORFER

e) analytical equipment HRGC/ECD

\section{Results}

In the biotope studied, as in many other locations in the Czech Republic, the size of the population of a number of animal species has decreased markedly, and the European hare has been no exception. A particular attention was paid to the natural vegetation at the location studied, which, together with crops grown there, make up the hares' diet. In 2001 - 2002, the author spotted five European hares in the area, which is very few compared with the past.

In the region studied, 62 species of herbs and grasses and 8 woody species were identified (Randuška et al. 1985).

It was established that European hares consumed 29 of the total of 62 plant species identified in the area and 6 of a total of 8 wood plant species (Table 1). Most of the species were plants grown on agricultural land in the area studied. It follows from the plant species diagnostic that plants consumed by hares include very many that are poorly digestible, and are therefore not suitable as food for hares. Their food composition depends on the time of the year, types of crop on the fields, and the quality of wild grass (fine spring grass, mature old grass).

Tests for the presence of PCB were performed using plants and European hare tissues as bioindicators of environmental stress. Two samples of a variety of dried plants were used, each weighing $1 \mathrm{~kg}$. Fresh samples of animal tissue, muscle and liver, were collected from bagged hares. The sum of 2 PCB congeners given in the table is in $\mathrm{mg}$ per $\mathrm{kg}$ of material.

Results of the tests in the muscle and liver tissues were statistically evaluated.

The mean values were 0.00033 and 0.00032 in the liver and muscles, respectively.

The standard deviations were 0.00015 and 0.00016 in the liver and muscles, respectively.

The coefficients of variations were $45 \%$ (liver) and $50 \%$ (muscles).

The average mean errors were 0.000032 (liver) and 0.000034 (muscles). 
Table 1. Cultivated species, ruderal plants and other vegetation, woody species

\begin{tabular}{|c|c|c|c|}
\hline Species & Family & Layer & Hares' diet \\
\hline Achillea millefolium & Asteraceae & herbal & included \\
\hline Aegopodium podagraria & Apiaceae & herbal & \\
\hline Agrostis canina & Poaceae & herbal & included \\
\hline Amaranthus retroflexus & Amaranthaceae & herbal & \\
\hline Anthriscus silvestris & Apiaceae & herbal & \\
\hline Arctium tomentosum & Asteraceae & herbal & \\
\hline Arrhenatherum elatius & Poaceae & herbal & included \\
\hline Artemisia vulgaris & Asteraceae & herbal & \\
\hline Atriplex patula & Chenopodiaceae & herbal & \\
\hline Atriplex sagittata & Chenopodiaceae & herbal & \\
\hline Beta vulgaris & Chenopodiaceae & herbal & included \\
\hline Ballota nigra & Lamiaceae & herbal & \\
\hline Brassica napus & Brassicaceae & herbal & included \\
\hline Bromus racemosus & Poaceae & herbal & included \\
\hline Calamagrostis epigeios & Poaceae & herbal & \\
\hline Carduus acanthoides & Asteraceae & herbal & \\
\hline Convolvulus arvensis & Convolvulaceae & herbal & \\
\hline Centauera jacea & Asteraceae & herbal & included \\
\hline Chaerophylum album & Apiaceae & herbal & \\
\hline Chaerophylum hirsutum & Apiaceae & herbal & \\
\hline Chaenopodium album & Chenopodioceae & herbal & \\
\hline Cichorium intibus & Asteraceae & herbal & included \\
\hline Cirsium arvense & Asteraceae & herbal & \\
\hline Dactylis glomerata & Poaceae & herbal & included \\
\hline Elytrigia repens & Poaceae & herbal & included \\
\hline Epilobium palustre & Onageraceae & herbal & \\
\hline Equisetum arvense & Equisetaceae & herbal & \\
\hline Euphorbia cyparissias & Euphorbiaceae & herbal & \\
\hline Festuca pratensis & Poaceae & herbal & included \\
\hline Festuca rubra & Poaceae & herbal & included \\
\hline Galinsoga parviflora & Asteraceae & herbal & \\
\hline Galium album & Rubiaceae & herbal & included \\
\hline Geranium pratense & Geraniaceae & herbal & \\
\hline Helianthus tuberosus & Asteraceae & herbal & included \\
\hline Heracleum sphondylium & Apiaceae & herbal & \\
\hline Hordeum vulgare & Poaceae & herbal & included \\
\hline Hypericum perforatum & Hypericaceae & herbal & \\
\hline Lamium album & Lamiaceae & herbal & \\
\hline Lamium purpureum & Lamiaceae & herbal & \\
\hline Leontodon hispidus & Asteraceae & herbal & \\
\hline Linaria vulgaris & Scrophulariaceae & herbal & \\
\hline Lolium perenne & Poaceae & herbal & included \\
\hline Pastinaca sativa & Apiaceae & herbal & included \\
\hline Phalaris arundinacea & Poaceae & herbal & included \\
\hline Plantago lanceolata & Plantaginaceae & herbal & included \\
\hline Plantago major & Plantaginaceae & herbal & included \\
\hline Polygonum aviculare & Polygonaceae & herbal & included \\
\hline Potentilla anserina & Rosaceae & herbal & \\
\hline Potentilla reptans & Rosaceae & herbal & \\
\hline
\end{tabular}


Table 1 continued. Cultivated species, ruderal plants and other vegetation, woody species

\begin{tabular}{|l|l|l|l|}
\hline Species & Family & Layer & Hare's diet \\
\hline Rubus caesius & Rosaceae & herbal & included \\
\hline Rumex crispus & Polygonaceae & herbal & included \\
\hline Rumex sanquineus & Polygonaceae & herbal & included \\
\hline Sinapis alba & Brassicaceae & herbal & included \\
\hline Solanum nigrum & Solanaceae & herbal & \\
\hline Solanum tuberosum & Solanaceae & herbal & included \\
\hline Sonchus arvensis & Asteraceae & herbal & \\
\hline Stellaria media & Caryophyllaceae & herbal & \\
\hline Tanacetum vulgare & Asteraceae & herbal & \\
\hline Taraxacum officinale & Asteraceae & herbal & included \\
\hline Tripleurospermum inodorum & Asteraceae & herbal & \\
\hline Triticum aestivum & Poaceae & herbal & included \\
\hline Zea mays & Poaceae & herbal & included \\
\hline Rosa canina & Rosaceae & bush & included \\
\hline Sambucus nigra & Sambucaceae & bush & \\
\hline Alnus glutinosa & Betulaceae & tree & \\
\hline Cerasus avium & Rosaceae & tree & included \\
\hline Fraxinus excelsior & Oleaceae & tree & included \\
\hline Prunus cerasifera & Rosaceae & tree & included \\
\hline Prunus domestica & Rosaceae & tree & included \\
\hline Pyrus communis & Rosaceae & \\
\hline
\end{tabular}

PCB concentrations in liver, muscle and plant samples ranged from 0.001 to 0.0007 $\mathrm{mg} / \mathrm{kg}$. PCB concentrations in the samples were in compliance with Czech food standards. Tests performed by the Veterinary Investigation Institute in Olomouc showed that PCB concentrations in tissue and liver samples of the European hare bagged near Senice were low. There must therefore be other reasons than PCB for the decrease in hare populations in the fields of this region.

\section{Discussion}

A total of 62 grasses and herbs and 8 woody species were identified. It was established that European hares in the region consumed 29 of the grass and herbal species and 6 woody species (see Results), which is not enough.

Kučera (1988) made a list of species very suitable to excellent as food for the European hare. They are the following: Thymus praecox, Petrosellinum crispum, Avena sativa, Triticum aestivum, Dactylis glomerata, Phleum pratense, Agrostis stolonifera, Festuca pratensis, Festuca rubra, Lolium perene, Pastinaca sativa, Medicago sativa, Trifolium campestre, Trifolium pratense, Trifolium repens, Trifolium medium, Capsulla bursa pastoris, Equisetum pratense, Brassica napus, Brassica rapa, Beta vulgaris, Daucus carota.

In the 2001 - 2002 survey, the following six species from Kučera's list (1988) of plants consumed by the European hare were found in the area investigated: Beta vulgaris, Lolium perenne, Festuca rubra, Dactylis glomerata, Pastinaca sativa, Triticum aestivum, Brassica napus, Agrostis canina, Festuca pratensis.

The following 21 plant species consumed by the European hare in the biotope investigated do not appear on Kučera's list (1988): Arrhenatherum elatius, Polygonum aviculare, Bromus racemosus, Galium album, Plantago major, Plantago lanceolata, Hordeum vulgare, Achillea millefolium, Helianthus tuberosus, Rumex crispus, Rubus caesius, Centaurea jacea, Sinapis alba, Stellaria media, Taraxacum officinale, Rumex 
Table 2. PCB congeners in mixed plant samples and the liver and muscle tissues of European hare in $\mathrm{mg} / \mathrm{kg}$ of material

\begin{tabular}{|c|c|c|c|c|}
\hline Sample No. & Tissue tested & $\begin{array}{c}\mathrm{PCB} \text { content } \\
\mathrm{mg} / \mathrm{kg}\end{array}$ & Sample No. & $\begin{array}{c}\text { PCB content } \\
\mathrm{mg} / \mathrm{kg}\end{array}$ \\
\hline \multirow{2}{*}{$\begin{array}{l}\text { Sample 1 } \\
\text { Sample 2 }\end{array}$} & Mixed plants 1 & 0.0005 & & \\
\hline & Mixed plants 2 & 0.0007 & & \\
\hline \multirow{2}{*}{1} & Liver & 0.0005 & \multirow{2}{*}{12} & 0.0004 \\
\hline & Muscle & 0.0003 & & 0.0002 \\
\hline \multirow{2}{*}{2} & Liver & 0.0005 & \multirow{2}{*}{13} & 0.0001 \\
\hline & Muscle & 0.0005 & & 0.0002 \\
\hline \multirow{2}{*}{3} & Liver & 0.0001 & \multirow{2}{*}{14} & 0.0001 \\
\hline & Muscle & 0.0002 & & 0.0002 \\
\hline \multirow{2}{*}{4} & Liver & 0.0006 & \multirow{2}{*}{15} & 0.0004 \\
\hline & Muscle & 0.0005 & & 0.0005 \\
\hline \multirow{2}{*}{5} & Liver & 0.0004 & \multirow{2}{*}{16} & 0.0005 \\
\hline & Muscle & 0.0006 & & 0.0005 \\
\hline \multirow{2}{*}{6} & Liver & 0.0004 & \multirow{2}{*}{17} & 0.0005 \\
\hline & Muscle & 0.0003 & & 0.0005 \\
\hline \multirow{2}{*}{7} & Liver & 0.0002 & \multirow{2}{*}{18} & 0.0004 \\
\hline & Muscle & 0.0001 & & 0.0001 \\
\hline \multirow[t]{2}{*}{8} & Liver & 0.0004 & \multirow{2}{*}{19} & 0.0002 \\
\hline & Muscle & 0.0005 & & 0.0001 \\
\hline \multirow{2}{*}{9} & Liver & 0.0003 & \multirow{2}{*}{20} & 0.0002 \\
\hline & Muscle & 0.0003 & & 0.0003 \\
\hline \multirow{2}{*}{10} & Liver & 0.0001 & \multirow{2}{*}{21} & 0.0004 \\
\hline & Muscle & 0.0001 & & 0.0003 \\
\hline \multirow{2}{*}{11} & Liver & 0.0002 & \multirow{2}{*}{22} & 0.0005 \\
\hline & Muscle & 0.0003 & & 0.0006 \\
\hline
\end{tabular}

sanguineus, Elytrigia repens, Phalaris arundinacea, Cichorium intibus, Solanum tuberosum, Zea mays.

Reporting on the situation in southern Moravia, Homolka (1982) described 111 plant species that constituted the trophic range. Green parts of herbs and grasses, forage crops and weeds predominated (Meriggi and Verri 1990). In winter, hares also gnawed at woody species. Trophic offer in a balanced biotope consists predominantly of grasses (up to 78\%) and includes woody species in winter $(20-40 \%)$ (Homolka 1982, 1987). The number of plant and woody species consumed by hares in the area investigated is small (29 and 6, respectively). The monodiet may have a negative impact on the European hare population in the area.

The establishment of large tracks of agricultural land and the ensuing reduction in the number of crops grown there ( 3 types) had a major impact on the scope of plants suitable for consumption by hares. Frequent digestive tract disorders in hares as a consequence of onesided diet have been reported by e.g. Hell and Nováková (1979).

The plants consumed by hares may transport PCBs to their organisms. Polychlorinated biphenyls are chlorine-based xenobiotic substances that have penetrated to all parts of the environment. They were first demonstrated by Jensen (1966) in his study of chlorinated insecticides. Since then, PCBs have been detected in soil, water, sediments, plants and animals (Piskač et al. 1990; Vávrová et al. 2003). PCBs are substances of oily consistency, resistant to photochemical or biological degradation. They are produced by controlled chlorination of biphenyl at the presence of ferric chloride as the catalyst. Its 
derivatives, e.g. chlorinated triphenyls, chlorinated dibenzofurans and dibenzodioxines, may also be potentially life-threatening (Kannan et al. 1987; Safe 1994). The WHO classification ranks PCBs among 2A compounds, i.e. carcinogenic substances that might cause the disease mainly in the liver, digestive tract and the lymphatic system. PCBs have been reported to have mutagenic and teratogenic effects, to interact with enzymes, particularly those of the endoplasmic reticulum, and to influence the metabolism of live organisms. Because PCB is contained in coating materials used in silage bunkers and silos, it might have easily penetrated into silages. PCBs have a mutagenic action and a negative effect on vitamin A levels ( B ukovjan et al. 1992). PCBs in aquatic ecosystems were found by B azzanti et al. (1997). The issue of PCB residues in European hares in central Bohemia was examined by Bukovjan et al. (1992). PCB in dolphins was found by Cardellicchio (1995), in turtles by Corsolini et al. (2000). Pis kač et al. (1990) monitored effects of PCB on the chicken organism. Vávrová et al. (2003) reported that small mammals living in the soil were good bioindicators of PCBs and heavy metals. In the Czech Republic, PCBs were first isolated in the environment and their residua in sediments and organisms reported by Vávrová et al. (2003).

Trpák (1984) reported that DDT, whose chemical structure is very similar to that of PCBs, was still influencing animal populations at the time. The disturbed homeostasis of the lowland area investigated led to disproportions in the propagation of predatory and herbivorous insects (aphids, flea beetles vs. ground beetles, etc.). That necessitated a more intensive use of pesticides, mainly insecticides and rodenticides with toxic and cumulative effects (DDT, HCH, Endrin), which caused acute and chronic poisoning and the death of animals, including European hares serving as bioindicators, fertility disorders and tumour growths.

Examinations of samples for PCB showed that its values were within the norm. In a comparison between results from the present study (see Table 2) and results of the examination of liver and muscle tissue samples of hares from central Moravia (lowland region around the town of Kroměříž) very similar PCB values were found, according to SVÚ Olomouc. The values found in about 20 samples ranged from 0.0001 to 0.0007 , i.e. they were approximately the same as the levels found in the area near Senice na Hané.

It is clear that the standard deviation is large. The tests have shown that PCB concentrations in dried mixed plant samples were higher than in animal tissues. PCB concentrations in muscles and liver were balanced, with slightly higher values found in the liver. The coefficient of variation is high, which means that the values measured are very variable.

The aim of the study was to determine all the plants growing in the area investigated, identify all plant species grazed by the European hare and to determine PCB presence in European hare using the screening test. The study was the first botanical study made in the area, and plant species that are consumed by hares and could participate in PCB transfer were identified.

\section{Hodnocení ekosystému na podkladě použítí bioindikátoru rostlinného a živočišného prostředí}

V práci byla nastíněna situace chemické zátěže BCP a spektra rostlin vhodných pro zajíce polního jako potrava v intenzivně zemědělsky obdělávané krajině u obce Senice na Hané, okr. Olomouc. V roce 2001 byl v této agrocenóze proveden botanický průzkum. Bylo zjištěno 60 druhů bylin a 9 druhů dřevin. Dále byly stanoveny druhy rostlin, které jsou pro zajíce polního poživatelné. Jednalo se o 21 druhů bylin a travin a 8 druhů dřevin. Byl proveden odběr vzorků rostlin, jater a svalu přední nebo zadní končetiny zajíce polního za účelem určení hladiny PCB. Pozitivním jevem je, že hodnota PCB je v normě (rostliny mají 
hodnotu od 0,0004 do 0,0007 mg, sval a játra od 0,0001 do 0,0005 mg). Cílem práce bylo stanovení všech druhů rostlin lokality, zjištění druhů rostlin, které slouží jako potrava zajíce polního a formou screeningového stanovení prokázání PCB u zajíce polního. Stanovení PCB bylo provedeno metodou HRGC/ECD. Z vědeckého hlediska je článek přínosem v tom, že lokalita byla zkoumána po botanické stránce a byly vyzkoumány druhy, které zajíc přijímá. Nejbližší údaje jsou z lokality Litovel. Zjistila se možnost kontaminace PCB $\mathrm{z}$ rostlin do těla zajíce.

\section{References}

BAZZANTI M, CHIAVARINI S, CREMISINI C, SOLDATI P 1997: Distribution of PCB congeners in aquatic ecosystems: A case study. Environ Int 23: 799-813

BUKOVJAN K, HOFFMAN V, BUKOVJANOVÁ E 1992: Chemical residues in hares: Occurrence of organochlorine compounds and PCB in adipose tissue from field hares in central Bohemia. Fleischwirtschaft 72: 339-341

CARDELLICCHIO N 1995: Persistant contaminats in dolphins: An indication of chemical pollution in the Mediterranean Sea. Water Sci Technol 32: 331-340

CORSOLINI S, ARIGI S, FOCARDI S 2000: Presence of polychlorbiphenyls (PCB) and coplanar congeners in the tissues of the Mediterranean Loggerheat turtle Caretta caretta. Mar Pollut Bull 40: 952-960

DYKYJOVÁ D 1989: Metody studia ekologie. Academia, Praha, 690 p.

FORMAN RTT, GODRON M 1993: Krajinná ekologie. Academia, Praha, 583 p.

HELL P, NOVÁKOVÁ E 1979: Zajíc polní jako ukazatel vlivu průmyslových imisí na CHKO Český kras. Památky a př́roda 8: 506- 509

HOMOLKA M 1982: The food of Lepus-europaeus in a meadow and woodlands complex. Folia Zool 31: 243-254

HOMOLKA M 1987: The diet of brown hare (Lepus-europaeus) in Central Bohemia. Folia Zool 36: 103-110

JENSEN S 1996: Report of a new chemical hazard. New Scientist 32: 612

JURAJDA P, BERNARDOVÁ I 1996: PCB in fish of the river Morava (Danube basin). A sampling approach. Folia Zool 45: 77-86

KANNAN N, TANABE S, WAKIMOTO T, TATSUKAWA R 1987: Coplanar polychlorinated biphenyls in Aroclor and Kanechlor mixtures. J Assoc Off Anal Chem 70: 451-454

KUČERA O 1988: Umělý chov zajíce. SZN, Praha, 304 p.

LIANG Y, PONK MH, SHUTES R, REVITT D 1999: Ecological risk assessment of polychlorinated bifenyl contamination in the Mai Po marshes nature reserve, Hongkong. Water Res 33: 1337-1346

MANOSA S, MATEO R, GUITART R 2001: A review of the effects of agricultural and industrial contamination on the Ebro delta biota and wildlife. Environ Monitor Asses 71: 187-205

MERIGGI A, VERRI A 1990: Population - dynamics and habitat selection of the European hare on popular monocultures in northern Italy. Acta Theriol 35: 69-76

PISKAČ A, RUPRICH J, HALOUZKA R 1990: Effect of polychlorinated-biphenyls (PCB) on the chickens organism - effect of a short-time administration of high-doses of delor-103 on the concentrations of thyroxine, triiodothyroxine, sodium, potassium and calcium in blood-serum. Vet Med Czech 35: 237- 246

RANDUŠKA D, SOMŠÁK L, HÁBEROVÁ I 1985: Barevný atlas rostlin. Vydavatelstvo Bratislava, nakladatelství Profil Ostrava

RASZYK J, GAJDUŠKOVÁ V, ULRICH R, JAROŠOVÁ A, ŠABATOVÁ V, SALAVA J, PALAC J 1996: Occurrence of chlorinated pesticides and polychlorinated biphenyls in the stable and outside stable environment of farms for pig fattening. Vet Med Czech 41: 165- 171

RASZYK J, TOMAN M, GAJDUŠKOVÁ V, NEZVEDA K, ULRICH R, JAROŠOVÁ A, DOČEKALOVÁ H, SALAVA J, PALAC J 1997: Effects of environmental pollutants on the porcine and bovine immune systems. Vet Med Czech 42: 313- 317

ROOTS O 1995: Organophosporine pesticides and polychlorinated - biphenyls in the ecosystem of the Baltic Sea. Chemosphere 31: 4085-4097

SAFE SH 1994: Polychlorinated biphenyls (PCBs) environmental- impact, biochemical and toxical responses, and implications for risk assessment Crit Rev Toxicol 24: 87

TRPÁK P 1984: Problémy ochrany zoogenofondu. Veterinární péče v chovech lovné zvěře 3

VÁVROVÁ M, GARGOŠOVÁ HZ, ŠUCMAN E, VEČEREK V, KOŘÍNEK P, ZUKAL J, ZEJDA J, SEBASTIANOVÁ N, KUBIŠTOVÁ I 2003: Game animals and small terrestrial mammals - suitable bioindicators for the pollution assessment in agrarian ecosystems. Fresen Environ Bull 12: 165-172 